\title{
UPAYA MENINGKATKAN PEMAHAMAN SISWA PADA MATERI HIMPUNAN DENGAN MENGGUNAKAN PENDEKATAN CONTEXTUAL TEACHING AND LEARNING (CTL)
}

\author{
Ayi Suhayi Nurhidayah \\ IKIP Siliwangi, Jl. Terusan Jendral Sudirman, Cimahi Tengah, Kota Cimahi, Jawa Barat \\ ayisuhayi26@gmail.com
}

\begin{abstract}
The material of the set is one of the basic concepts that must be mastered by students of class VII in order to facilitate students in learning other mathematical material. The purpose of writing this PTK report is: 1) To know students' understanding of the material set in class VII A SMP Negeri 1 Cisarua, West Bandung Regency before and after using the CTL (Contextual Teaching and Learning) approach. 2) To find out the effectiveness of the effective CTL (Contextual Teaching and Learning) approach is used to improve students' understanding of the set material in class VII A SMP Negeri 1 Cisarua, West Bandung Regency. 3) To find out the differences in the results of increasing students' understanding of the material set in class VII A SMPN 1 Cisarua, West Bandung Regency before and after using the CTL (Contextual Teaching and Learning) approach.
\end{abstract}

Keywords: Understanding, Set, CTL (Contextual Teaching and Learning).

\begin{abstract}
Abstrak
Materi himpunan merupakan salah satu konsep dasar yang harus dikuasai siswa kelas VII guna mempermudah siswa dalam mempelajari materi matematika yang lain. Tujuan penulisan laporan PTK ini adalah: 1) Untuk mengtahui pemahaman siswa pada materi himpunan di kelas VII A SMP Negeri 1 Cisarua Kabupaten Bandung Barat sebelum dan sesudah menggunakan pendekatan CTL (Contextual Teaching and Learning). 2) Untuk mengetahui keefektifan pendekatan CTL (Contextual Teaching and Learning) efektif digunakan untuk meningkatkan pemahaman siswa pada materi himpunan di kelas VII A SMP Negeri 1 Cisarua Kabupaten Bandung Barat. 3) Untuk mengetahui adanya perbedaan hasil peningkatan pemahaman siswa pada materi himpunan di kelas VII A SMP Negeri 1 Cisarua Kabupaten Bandung Barat sebelum dan sesudah menggunakan pendekatan CTL (Contextual Teaching and Learning).
\end{abstract}

Kata kunci: Pemahaman, Himpunan, CTL (Contextual Teaching and Learning)

Matematika merupakan wahana pendidikan tidak hanya dapat digunakan untuk mencapai satu tujuan yakni mencerdaskan siswa, namun juga untuk membentuk kepribadian siswa, mengembangkan keterampilan tertentu dan pengetahuan secara kognitif (Hidayat, Akbar \& Bernard, 2019) serta mengaplikasikan ke kehidupan sehari-hari (Isnaeni, et. al, 2019; Akbar, et. al, 2018; Sugandi \& Akbar, 2019). Mengingat pentingnya matematika dalam ilmu pengetahuan dan teknologi, maka matematika perlu dikuasai dan dipahami dengan baik oleh segenap lapisan masyarakat, terutama siswa sekolah formal disemua jenjang pendidikan, sehingga manusia dapat memikirkan, mencatat, dan mengkomunikasikan ide mengenai elemen dan kuantitas (Bernard, et. al., 2019; Lerner dalam Mulyono, 2003:252; Nurhayati, 2019; Wiliawanto, 2019).

Belajar Matematika di sekolah menengah sering menjadi beban bagi siswa (Bernard, Sumarna, Rolina, \& Akbar, 2019), dimana siswa sering kesulitan dalam mempelajari banyak materi di sekolah menengah pertama (SMP), salahsatunya materi himpunan. Materi himpunan adalah materi tentang kumpulan benda-benda yang didefinisikan (diberi batasan) dengan jelas. Materi ini diajarkan kepada siswa kelas VII SMP/MTs pada Semester I. Oleh karena itu, materi himpunan merupakan materi dasar yang harus dikuasai oleh siswa SMP/MTs, khususnya kelas VII.

Materi himpunan adalah salah satu materi penting yang diajarkan kepada siswa SMP dan dapat 
digunakan untuk menyelesaikan masalah dalam kehidupan sehari-hari di mana siswa dituntut untuk harus dikuasai siswa guna mempermudah siswa dalam mempelajari materi matematika yang lain. Oleh karena itu, materi himpunan menjadi penting untuk dikuasai oleh siswa kelas VII di tingkat sekolah menengah pertama. Dengan menguasai materi himpunan, maka materi matematika lainnya akan lebih mudah untuk dipahami.

Berdasarkan studi pendahuluan yang penulis lakukan di SMP Negeri 1 Cisarua Kabupaten Bandung Barat melalui observasi, penulis mendapatkan bahwa siswa mengalami masalah dalam memahami dan memecahkan soal materi himpunan. Hal ini disebabkan karena siswa kurang memahami konsep dasar himpunan dan tidak memahami apa yang dibaca, sehingga masih banyak siswa yang mengalami kesulitan dalam memahami dan menyelesaikan soal pada materi himpunan. Adapun kendala yang dihadapi siswa yaitu sulit menerjemahkan bahasa tekstual himpunan ke dalam bahasa sehari-hari, siswa merasa masih asing dengan istilah ilmiah matematika khususnya materi himpunan yang ditemui di dalam soal, kemampuan siswa menganalisa soal masih rendah, dan sulit menerjemahkan perintah soal cerita ke dalam model himpunan sehingga keliru dalam menyelesaikannya. Berdasarkan gambaran di atas, adapun masalah yang sering dialami oleh siswa pada materi himpunan terkait soal berbentuk cerita disebabkan karena siswa kurang memahami konsep dasar, mengidentifikasi simbol (Bernard \& Senjayawati, 2019; Rohaeti, 2019), tidak memahami apa yang dibaca, dan tidak mampu menerjemahkan soal cerita kedalam model matematika, serta tidak memahami langkah-langkah penyelesaian soal yang diberikan (Bernard \& Senjayawati, 2019).

Melihat permasalah di atas, maka diperlukan upaya-upaya untuk meningkatkan pemahaman siswa terhadap materi himpunan di kelas VII. Hal ini merupakan tanggung jawab guru dengan kompetensi-kompetensi dasar yang dimiliki, guru harus dapat mengemas pelaksanaan proses pembelajaran, dengan menyiapkan materi dan bahan ajar yang akan disampaikan yang dirancang dengan menggunakan pendekatan metode, model pembelajaran, dan sumber belajar yang tepat sesuai dengan kondisi dan karakteristik siswa (insani et. al., 2019), salah satunya adalah dengan menggunakan pendekatan CTL (Contextual Teaching and Learning). Pendekatan CTL (Contextual Teaching and Learning) adalah konsep belajar yang membantu guru mengaitkan antara materi yang diajarkannya dengan situasi dunia nyata siswa dan mendorong siswa membuat hubungan antara pengetahuan yang dimilikinya dengan penerapannya dalam kehidupan mereka sebagai anggota keluarga dan masyarakat. Melalui konsep tersebut, hasil pembelajaran dihadapkan lebih bermakna bagi siswa. Proses pembelajaran berlangsung alamiah dalam bentuk kegiatan siswa bekerja dan mengalami, bukan transfer pengetahuan dari guru ke siswa (Saliman, 2009:12).

Berdasarkan permasalahan tersebut di atas, penulis tertarik untuk melakukan Penelitian Tindakan Kelas (PTK) dengan bahasan yang berjudul, "Upaya Meningkatkan Pemahaman Siswa pada Materi Himpunan dengan Menggunakan Pendekatan CTL (Contextual Teaching and Learning) di Kelas VII A SMP Negeri 1 Cisarua Kabupaten Bandung Barat”. Tujuan Penelitian Tindakan Kelas (PTK) ini 
adalah: 1) Untuk mengetahui pemahaman siswa pada materi himpunan di kelas VII A SMP Negeri 1 Cisarua Kabupaten Bandung Barat sebelum dan sesudah menggunakan pendekatan CTL (Contextual Teaching and Learning). 2) Untuk mengetahui keefektifan pendekatan CTL (Contextual Teaching and Learning) efektif digunakan untuk meningkatkan pemahaman siswa pada materi himpunan di kelas VII A SMP Negeri 1 Cisarua Kabupaten Bandung Barat. 3) Untuk mengetahui adanya perbedaan hasil peningkatan pemahaman siswa pada materi himpunan di kelas VII A SMP Negeri 1 Cisarua Kabupaten Bandung Barat sebelum dan sesudah menggunakan pendekatan CTL (Contextual Teaching and Learning).

\section{METODE}

Sesuai dengan masalah yang diteliti, maka jenis penelitian yang dilakukan oleh peneliti berupa Penelitian Tindakan Kelas (PTK), yaitu suatu kegiatan penelitian yang dilakukan di kelas dalam arti luas. Suharsimi Arikunto (2006:2) menyatakan bahwa: Penelitian Tindakan Kelas sebagai bentuk penelitian yang bertujuan untuk meningkatkan hasil belajar siswa, sehingga penelitian harus menyangkut upaya guru dalam bentuk proses pembelajaran. PTK, selain bertujuan untuk meningkatkan hasil belajar, juga untuk meningkatkan kinerja guru dan dosen dalam proses pembelajaran. Tampubolon (2014:19) penelitian tindakan kelas adalah penelitian yang dilakukan oleh pendidik/ calon pendidik di dalam kelasnya sendiri secara kolaboratif/partisipatif untuk memperbaiki kinerja pendidik menyangkut kualitas proses pembelajaran, dan meningkatkan hasil belajar peserta didik, baik dari aspek akademik maupun nonakademik, melalui tindakan reflektif dalam bentuk siklus (daur ulang). IGAK Wardhani (2008: 1.4) penelitian tindakan kelas adalah penelitian yang dilakukan oleh guru di dalam kelasnya sendiri melalui refleksi diri, dengan tujuan untuk memperbaiki kinerjanya sebagai guru, sehingga hasil belajar siswa menjadi meningkat.

Menurut Ditjen PMPTK (2010:7) Tujuan utama PTK adalah untuk memecahkan permasalahan nyata yang terjadi di dalam kelas sekaligus mencari jawaban ilmiah mengapa hal tersebut dapat dipecahkan melalui tindakan yang akan dilakukan. PTK juga bertujuan untuk meningkatkan kegiatan nyata guru dalam pengembangan profesinya. Tujuan khusus PTK adalah untuk mengatasi berbagai persoalan nyata guna memperbaiki atau meningkatkan kualitas proses pembelajaran di kelas.

Bagian ini berisi sub bagian dari Metode. Penulis dapat menggunakan style heading 2 untuk sub judul. Penulis dapat menggunakan style heading ini untuk di sub judul di bagian lain di dalam manuscript ini. Banyak ahli yang mengemukakan model Penelitian Tindakan Kelas (PTK) dengan bagan yang berbeda-beda, namun secara garis besar terdapat empat tahapan yang dilalui, yaitu: (1) tahap rencana, (2) tahap tindakan, (3) tahap observasi/evaluasi, (4) tahap refleksi. Penelitian tindakan kelas ini dilaksanakan ke dalam siklus. Setiap siklus dalam Penelitian Tindakan Kelas (PTK) ini terdiri dari empat tahapan yaitu rencana, tindakan, observasi, dan refleksi. 


\section{HASIL}

Pada pertemuan 1 sebelum PTK dilaksanakan peneliti menggunakan instrument angket tentang teks ulasan yang dibagikan kepada seluruh siswa. Yang pada akhirnya dipakai tolak ukur perbandingan sebelum ada tindakan kelas dengan sesudah ada tindakan kelas. Peneliti hanya mengamati proses belajar mengajar. Di akhir pembelajaran, peneliti membagikan angket sebelum PTK untuk mengetahui seberapa besar pemahaman siswa terhadap teks ulasan, literasi, dan buletin sekolah.

\section{Tabel 1.}

Hasil Tes Angket (Quesioner) Siswa Sebelum PTK

\begin{tabular}{|c|l|c|c|}
\hline \multirow{2}{*}{ No } & \multicolumn{1}{|c|}{ Aspek yang Dinilai } & \multicolumn{1}{|c|}{ Pernyataan } \\
\cline { 3 - 4 } & \multicolumn{1}{|c|}{ Ya } & Tidak \\
\hline 1 & Apakah materi himpunan dapat meningkatkan kemampuanmu dalam berpikir kritis? & $10 \%$ & $90 \%$ \\
\hline 2 & Apakah materi himpunan dapat meningkatkan kemampuanmu dalam berpikir logis? & $6 \%$ & $94 \%$ \\
\hline 3 & $\begin{array}{l}\text { Apakah materi himpunan dapat meningkatkan kemampuan mu dalam berpikir secara } \\
\text { sistematis? }\end{array}$ & $5 \%$ & $95 \%$ \\
\hline 4 & $\begin{array}{l}\text { Apakah materi himpunan dapat membantu mu mempermudan untuk mempelajari } \\
\text { materi yang lain? }\end{array}$ & $10 \%$ & $90 \%$ \\
\hline 5 & $\begin{array}{l}\text { Apakah materi himpunan menjadikan kamu lebih mampu melakukan analisis } \\
\text { terhadap suatu peristiwa atau kejadian? }\end{array}$ & $9 \%$ & $91 \%$ \\
\hline
\end{tabular}

Pada siklus 1 kegiatan belajar dilakukan dengan model kerja kelompok sesuai dengan rencana tindakan. Berdasarkan data pengamatan penelitian hasilnya menunjukkan bahwa siswa sebenarnya telah mampu beradaptasi, namun, masih terdapat banyak kekurangan sehingga pada tahap ini belum terlihat adanya pertumbuhan pemahaman terhadap materi himpunan. Berdasarkan data di siklus 1, diperoleh hasil pemahaman siswa kelas VII A SMP Negeri 1 Cisarua Kabupaten Bandung Barat sebelum penerapan literasi melalui buletin sekolah, jumlah siswa 35 orang mengikuti tes awal dinyatakan 8 orang lulus $(17,14 \%)$ dan yang tidak lulus 27 orang $(77,15 \%)$ dengan nilai rata-rata 58,43 , dengan KKM (Kriteria Ketuntasan Minimal) 70. Berdasarkan hasil refleksi, yakni kegiatan belajar mengajar peneliti menemukan beberapa poin yang harus diperbaiki oleh peneliti (guru) yakni: (a) Antusias siswa dalam mengikuti pembelajaran materi himunan sangat kurang; (b) Pemahaman siswa dalam mengidentifikasi informasi tentang materi dasar himpunan sangat kurang. c) Pemahaman siswa dalam menyelesaikan soal pada materi himpunan sangat kurang.

Adapun kendala yang dihadapi siswa yaitu sulit menerjemahkan bahasa tekstual himpunan ke dalam bahasa sehari-hari, siswa merasa masih asing dengan istilah ilmiah matematika khususnya materi himpunan yang ditemui di dalam soal, kemampuan siswa menganalisa soal sangat rendah, dan sulit menerjemahkan perintah soal cerita ke dalam model himpunan sehingga keliru dalam menyelesaikannya. Berdasarkan gambaran di atas, adapun masalah yang sering dialami oleh siswa pada materi himpunan terkait soal berbentuk cerita disebabkan karena siswa kurang memahami konsep dasar, tidak memahami apa yang dibaca, dan tidak mampu menerjemahkan soal cerita kedalam model matematika, serta tidak memahami langkah-langkah penyelesaian soal yang diberikan. 
Atas dasar hasil penelitian tersebut di atas, diperoleh simpulan sebagai berikut: 1) Budaya baca siswa masih rendah sehingga minat baca sebagai sikap positif dan adanya rasa keterikatan dalam diri terhadap aktivitas pada pemahaman materi himpunan sangat kurang. 2) Guru harus mengarahkan siswa agar dapat mengembangkan kemampuan individu, sehingga siswa mampu menggunakan potensi dan keterampilan dalam mengolah informasi. 3) Langkah-langkah pengerjaan tugas baik tugas individu maupun kelompok harus dijelaskan secara terperinci oleh guru. 4) Guru harus memberitahukan atau menekanankan kepada siswa tentang adanya penilaian proses kegiatan belajar.

Pada siklus 2 kegiatan belajar dilakukan dengan menggunakan pendekatan CTL (Contextual Teaching and Learning), peneliti melihat adanya peningkatan pemahaman pada materi himpunan. Hal tersebut terbukti dari data hasil pengamatan yang dilakukan oleh peneliti, dan berdasarkan data hasil siklus 2. Berdasarkan data siklus 2, diperoleh hasil pemahaman siswa kelas VII A SMP Negeri 1 Cisarua Kabupaten Bandung Barat sebelum penerapan literasi melalui buletin sekolah, jumlah siswa 35 orang mengikuti tes awal dinyatakan 29 orang lulus $(71,43 \%)$ dan yang tidak lulus 6 orang $(28,57 \%)$ dengan nilai rata-rata 72,86, dengan KKM (Kriteria Ketuntasan Minimal) 70.

Berdasarkan hasil refleksi, yakni kegiatan belajar mengajar peneliti menemukan beberapa poin yang harus diperbaiki oleh peneliti (guru) yakni: (a) Antusias siswa dalam mengikuti pembelajaran materi himunan masih kurang; (b) Pemahaman siswa dalam mengidentifikasi informasi tentang materi dasar himpunan masih kurang. c) Pemahaman siswa dalam menyelesaikan soal pada materi himpunan masih kurang. Adapun kendala yang dihadapi siswa yaitu sulit menerjemahkan bahasa tekstual himpunan ke dalam bahasa sehari-hari, siswa merasa masih asing dengan istilah ilmiah matematika khususnya materi himpunan yang ditemui di dalam soal, kemampuan siswa menganalisa soal masih rendah, dan sulit menerjemahkan perintah soal cerita ke dalam model himpunan sehingga keliru dalam menyelesaikannya. Berdasarkan gambaran di atas, adapun masalah yang sering dialami oleh siswa pada materi himpunan terkait soal berbentuk cerita disebabkan karena siswa masih kurang memahami konsep dasar, tidak memahami apa yang dibaca, dan tidak mampu menerjemahkan soal cerita kedalam model matematika, serta tidak memahami langkah-langkah penyelesaian soal yang diberikan.

Atas dasar hasil penelitian tersebut di atas, diperoleh simpulan sebagai berikut: 1) Siswa belum mengenal pendekatan CTL (Contextual Teaching and Learning) yang menekankan aktivitas berpikir siswa secara penuh, baik fisik maupun mental. 2) Guru harus mengarahkan siswa agar lebih dapat mengembangkan kemampuan individu, sehingga siswa mampu menggunakan potensi dan keterampilan dalam mengolah informasi. 3) Langkah-langkah pengerjaan tugas baik tugas individu maupun kelompok harus dijelaskan secara lebih terperinci oleh guru. 4) Guru harus memberitahukan atau menekanankan kepada siswa tentang adanya penilaian proses kegiatan belajar.

Berdasarkan hasil penelitian di atas, maka ditetapkan rencana tindakan untuk siklus berikutnya, yaitu siklus 3. Pada siklus 3 ini kegiatan membaca sebelum membahas materi menjadi kegiatan wajib yang dilakukan oleh siswa, karena penguasaan konsep dan ruang lingkup materi tentang himpunan sangat penting karena semua cabang-cabang matematika bertumpu pada konsep dasar dan teori 
himpunan. Penguasaan konsep dan teori himpunan yang memadai akan bermanfaat bagi siswa.

Upaya perbaikan yang dilakukan pada kegiatan siklus 3 dengan menggunakan pendekatan CTL (Contextual Teaching and Learning), peneliti melihat adanya peningkatan pemahaman pada materi himpunan. Hal tersebut terbukti dari data hasil pengamatan yang dilakukan oleh peneliti, dan berdasarkan data hasil siklus 3. Dari data siklus 3, diperoleh hasil pemahaman siswa Kelas VII A SMP Negeri 1 Cisarua pada materi himpunan semakin meningkat jumlah siswa 35 orang yang mengikuti tes akhir dengan menggunakan pendekatan CTL (Contextual Teaching and Learning), ternyata 35 orang dinyatakan lulus (100\%) karena nilai yang diperolehnya telah melebihi KKM (Kriteria Ketuntasan Minimal) 70 .

\section{Siklus 1}

Perencanaan. Tahap perencanaan pada siklus 1 meliputi: a) Perencaan pembelajaran yang dilaksanakan menggunakan metode diskusi sesuai yang tertera dalam Rencana Pelaksanaan Pembelajaran (RPP). b) Menentukan pokok-pokok bahasan. c) Mengembangkan skenario pembelajaran. d) Menyiapkan instrumen. e) Menyiapkan sumber belajar.

Tindakan. Tahap tindakan yaitu prose pembelajaran dilaksanakan dengan mengguna-kan metode diskusi yang sesuai tertera pada Rencana Pelaksanaan Pembelajaran (RPP).

Tahap Observasi (Pengamatan). Hasil observasi (pengamatan) pada siklus 1, yaitu: a) Tahap awal proses pembelajaran suasana belum kondusif disebabkan siswa belum terbiasa mengikuti proses pembelajaran materi himpunan. b) Tahap diskusi belum berjalan dengan baik. Pada saat mengajukan pertanyaan masih ada siswa yang bercanda dengan temannya dan pertanyaan yang diajukan masih bersifat nonproduktif dan tidak sesuai dengan indikator. c) Tahap pelaksanaan investigasi atau pengamatan, kerjasama kelompok belum terjalin dengan baik, sebagian besar dari siswa masih mengandalkan siswa atau temannya yang pandai. d) Tahap presentasi hasil, siswa belum terlihat berani mempresentasikan hasil kerja sama kelompoknya, karena siswa belum terbiasa untuk mempresentasikan hasil kerja sama kelompoknya dalam forum kelas.

Refleksi. Refleksi pada siklus 1: a) Tahap awal proses pembelajaran belum kondusif karena siswa belum terbiasa mengikuti pelajaran materi himpunan, sehingga guru harus memperkenalkan materi himpunan lebih aktif. b) Tahap diskusi belum berjalan dengan baik. Pada saat mengajukan pertanyaan masih ada siswa yang bercanda dengan temannya dan pertanyaan yang diajukan masih bersifat nonproduktif, sehingga guru harus mengarahkan siswa agar siswa mengajukan pertanyaan yang bersifat produktif. c) Tahap pelaksanaan investigasi atau pengamatan, kerjasama kelompok belum terjalin dengan baik, sebagian besar dari siswa masih mengandalkan siswa atau temannya yang pandai, sehingga guru harus mengarahkan siswa agar siswa lebik aktif secara individu. d) Tahap presentasi hasil, siswa belum terlihat berani mempresentasikan hasil kerjasama kelompok-nya, karena siswa belum terbiasa untuk mempresentasikan hasil kerjasama dalam kelompoknya, sehingga guru harus mengarahkan siswa agar berani mempresentasikan hasil kerjasama kelompoknya. e) Pada akhir 
pertemuan siklus 1 dilakukan tes untuk mengetahui pengetahuan awal yang dimiliki oleh siswa dan diperoleh data hasil belajar nilai rata-rata 58,43 di bawah Kriteria Ketuntasan Minimum (KKM) 70 dengan kelulusan $22,85 \%$.

Keputusan. Keputusan hari hasil siklus 1 ini sebagai berikut: a) Guru harus mengarahkan dan memberi masukan agar siswa memfokuskan pada proses pembelajaran. b) Guru harus mengarahkan dan memberi masukan agar siswa mengajukan pertanyaan yang bersifat produktif. c) Guru harus mengarahkan siswa agar lebih aktif secara individu dalam kegiatan menginvestigasi. d) Guru harus mengarahkan siswa agar berani mempresentasikan hasil kerjasama kelompoknya.Level pertama bullet.

\section{Siklus 2}

Perencanaan. Tahap perencanaan pada siklus 2 meliputi: a) Perencaan pembelajaran yang akan dilaksanan melalui penerapan pendekatan CTL (Contextual Teaching and Learning). b) Menentukan pokok-pokok bahasan. c) Mengembangkan skenario pembelajaran. d) Menyiapkan instrument. e) Menyiapkan sumber belajar.

Tindakan. Tahap tindakan yaitu penerapan pendekatan CTL (Contextual Teaching and Learning) sesuai yang tertera pada Rencana Pelaksanaan Pembelajaran (RPP).

Tahap Observasi (Pengamatan). Hasil observasi (pengamatan) pada siklus 2, yaitu: a) Tahap awal proses pembelajaran suasananya mulai kondusif, siswa sudah mengikuti pelajaran dengan baik sesuai dengan langkah-langkah pendekatan CTL (Contextual Teaching and Learning) sesuai arahan dari guru. b) Siswa mulai mampu menanggapi materi pengayaan tentang himpunan secara lisan dan tulisan; c) Siswa mulai mampu membangun interaksi antarsiswa dan antara siswa dengan guru tentang materi himpunan; e) Siswa mulai mampu untuk berpikir kritis, analitis, kreatif, dan inovatif; f) Siswa mulai mampu mencari keterkaitan antara materi yang dipelajari dengan diri sendiri dan lingkungan sekitarnya.

Refleksi. Refleksi pada siklus 2: a) Tahap awal, kegiatan pembelajaran suasananya mulai kondusip, siswa sudah mengikuti pelajaran dengan baik dan mengenal pendekatan CTL (Contextual Teaching and Learning), tetapi guru masih harus memberikan masukan agar siswa lebih meningkatkan kegiatan belajarnya sehingga siswa mampu mengembangkan kemampuan memahami materi himpunan dan mengaitkannya dengan pengalaman pribadi sehingga terbentuk pribadi pembelajar sepanjang hayat. b) Tahap pembiasaan, melalui kolaborasi siswa seyogyanya dibiasakan saling belajar di dalam kelompoknya untuk berbagai pengetahuan dan menentukan fokus belajar. Dalam setiap kolaborasi selalu ada siswa yang menonjol dibandingkan dengan yang lainnya. Dia dapat dijadikan fasilitator kelompoknya. Apabila peran fasilitator sudah terbina sedemikian rupa di sekolah, guru tentu akan lebih berperan sebagai pelatih, fasilitator, dan mentor. c) Tahap pengembangan, mengembangkan lingkungan fisik, sosial, afektif dan menciptakan ekosistem sekolah yang menghargai keterbukaan dan kegemaran terhadap pengetahuan dengan berbagai kegiatan, antara lain: (a) memberikan penghargaan kepada capaian perilaku positif, kepedulian sosial, dan semangat belajar peserta didik; penghargaan ini dapat dilakukan pada setiap upacara bendera hari Senin dan/atau peringatan lain; (b) kegiatan-kegiatan 
akademik lain (belajar di kebun sekolah, belajar di lingkungan luar sekolah, wisata perpustakaan kota/daerah dan taman bacaan masyarakat, dll ) d) Tahap pembelajaran, memberdayakan siswa untuk belajar sendiri. Setiap manusia mesti menjadi pembelajar sepanjang hayat. Jadi, pendidikan merupakan tempat penggodogan bagi siswa untuk menguasai cara belajar untuk belajar mandiri dikemudian hari. Untuk itu mereka harus dilatih berpikir kritis dan kreatif dalam mencari dan menganalisis informasi dengan sedikit bantuan atau secara mandiri. e) Pada akhir pertemuan dilakukan tes akhir untuk mengetahui hasil belajar siswa dan diperoleh data hasil belajar nilai rata-rata 91,71 di atas Kriteria Ketuntasan Minimum (KKM) 70 dengan kelulusan 97,15\%.

Keputusan. Keputusan hasil siklus 2 yaitu penerapan pendekatan CTL (Contextual Teaching and Learning) dapat meningkatkan pemahaman siswa pada materi himpunan, hal tersebut dapat dilihat dari data hasil tes pemahaman siswa pada materi himpunan dalam setiap siklusnya mengalami peningkatan yang baik. Pada siklus 1 nilai rata-rata yang diperoleh 58,42 di bawah Kriteria Ketuntasan Minimum (KKM) 70 dengan kelulusan 17,14\%, sedangkan pada siklus 2 dan nilai rata-rata yang diperoleh 72,86 di atas Kriteria Ketuntasan Minimum (KKM) 70 dengan kelulusan 71,43\%.

\section{Siklus 3}

Perencanaan. 1) Tahap perencanaan pada siklus 2 meliputi: a) Perencaan pembelajaran yang akan dilaksanan melalui penerapan pendekatan CTL (Contextual Teaching and Learning). b) Menentukan pokok-pokok bahasan. c) Mengembangkan skenario pembelajaran. d) Menyiapkan instrument. e) Menyiapkan sumber belajar.

Tindakan. Tahap tindakan yaitu penerapan pendekatan CTL (Contextual Teaching and Learning) sesuai yang tertera pada Rencana Pelaksanaan Pembelajaran (RPP).

Tahap Observasi (Pengamatan). Hasil observasi (pengamatan) pada siklus 3, yaitu: a) Tahap awal proses pembelajaran suasananya sudah kondusif, siswa sudah mengikuti pelajaran dengan baik sesuai dengan langkah-langkah pendekatan CTL (Contextual Teaching and Learning) sesuai arahan dari guru. b) Siswa sudah mampu menanggapi materi pengayaan tentang himpunan secara lisan dan tulisan; c) Siswa sudah mampu membangun interaksi antarsiswa dan antara siswa dengan guru tentang materi himpunan; d) Siswa sudah mampu untuk berpikir kritis, analitis, kreatif, dan inovatif; e) Siswa sudah mampu mencari keterkaitan antara materi yang dipelajari dengan diri sendiri dan lingkungan sekitarnya.

Refleksi. Refleksi pada siklus 3: a) Tahap awal, kegiatan pembelajaran suasananya kondusip, siswa sudah mengikuti pelajaran dengan baik dan mengenal pendekatan CTL (Contextual Teaching and Learning), tetapi guru masih harus memberikan masukan agar siswa lebih meningkatkan kegiatan belajarnya sehingga siswa mampu mengembangkan kemampuan memahami materi himpunan dan mengaitkannya dengan pengalaman pribadi sehingga terbentuk pribadi pembelajar sepanjang hayat. b)

Tahap pembiasaan, melalui kolaborasi siswa seyogyanya dibiasakan saling belajar di dalam kelompoknya untuk berbagai pengetahuan dan menentukan fokus belajar. Dalam setiap kolaborasi 
selalu ada siswa yang lebih menonjol dibandingkan dengan yang lainnya. Dia dapat dijadikan fasilitator kelompoknya. Apabila peran fasilitator sudah terbina sedemikian rupa di sekolah, guru tentu akan lebih berperan sebagai pelatih, fasilitator, dan mentor. c) Tahap pengembangan, mengembangkan lingkungan fisik, sosial, afektif dan menciptakan ekosistem sekolah yang menghargai keterbukaan dan kegemaran terhadap pengetahuan dengan berbagai kegiatan, antara lain: (a) memberikan penghargaan kepada capaian perilaku positif, kepedulian sosial, dan semangat belajar peserta didik; penghargaan ini dapat dilakukan pada setiap upacara bendera hari Senin dan/atau peringatan lain; (b) kegiatan-kegiatan akademik lain (belajar di kebun sekolah, belajar di lingkungan luar sekolah, wisata perpustakaan kota/daerah dan taman bacaan masyarakat, dll.) d) Tahap pembelajaran, memberdayakan siswa untuk belajar sendiri. Setiap manusia mesti menjadi pembelajar sepanjang hayat. Jadi, pendidikan merupakan tempat penggodogan bagi siswa untuk menguasai cara belajar untuk belajar mandiri dikemudian hari. Untuk itu mereka harus dilatih berpikir kritis dan kreatif dalam mencari dan menganalisis informasi dengan sedikit bantuan atau secara mandiri. e) Pada akhir pertemuan dilakukan tes akhir untuk mengetahui hasil belajar siswa dan diperoleh data hasil belajar nilai rata-rata 94 di atas Kriteria Ketuntasan Minimum (KKM) 70 dengan kelulusan 100\%.

Keputusan. Keputusan hasil siklus 3 yaitu penerapan pendekatan CTL (Contextual Teaching and Learning) dapat meningkatkan pemahaman siswa pada materi himpunan, hal tersebut dapat dilihat dari data hasil tes pemahaman siswa pada materi himpunan dalam setiap siklusnya mengalami peningkatan yang sangat baik. Pada siklus 1 nilai rata-rata yang diperoleh 58,43 di bawah Kriteria Ketuntasan Minimum (KKM) 70 dengan kelulusan 22,85\%, sedangkan pada siklus 2 nilai rata-rata yang diperoleh 72,86 di atas Kriteria Ketuntasan Minimum (KKM) 70 dengan kelulusan 71,43\%, pada siklus 3 nilai rata-rata yang diperoleh 94 di atas Kriteria Ketuntasan Minimum (KKM) 70 dengan kelulusan $100 \%$. Berikut tabel prosentase peningkatan hasil pemahaman siswa pada materi himpunan dalam siklus 1, 2 dan 3:

Tabel 2.

Prosentase Peningkatan Hasil Tes Pemahaman Siswa pada Materi Himpunan Siklus 1, 2, dan 3

\begin{tabular}{|c|l|c|c|c|}
\hline \multirow{2}{*}{ No } & \multicolumn{1}{|c|}{ Kegiatan/Aspek yang Dinilai } & \multicolumn{3}{|c|}{ Prosentase (\%) } \\
\cline { 3 - 5 } & \multicolumn{1}{|c|}{ Siklus 1 } & Siklus 2 & $\begin{array}{c}\text { Siklus } \\
\mathbf{3}\end{array}$ \\
\hline 1. & Antusias siswa dalam mengikuti pembelajaran materi himpunan. & 45 & 74 & 96 \\
\hline 2. & Kemampuan siswa dalam menyajikan himpunan dengan kata-kata & 47 & 70 & 93 \\
\hline 3. & Kemampuan siswa menyajikan notasi pembentukan himpunan & 46 & 75 & 97 \\
\hline 4. & $\begin{array}{l}\text { Kemampuan menyajikan dengan menndaftar anggota-anggota } \\
\text { himpunan }\end{array}$ & 43 & 71 & 95 \\
\hline 5. & $\begin{array}{l}\text { Kemampuan siswa dalam mengerjakan soal himpunan dengan tipe } \\
\text { yang berbeda }\end{array}$ & 40 & 72 & 92 \\
\hline
\end{tabular}


Berdasarkan hasil observasi yang dilakukan peneliti pada siklus 1 ditemukan data: (1) antusias siswa dalam mengikuti pembelajaran materi himpunan 45\%. (2) kemampuan siswa dalam menyajikan himpunan dengan kata-kata 47\%. (3) kemampuan siswa menyajikan notasi pembentukan himpunan 46\%. (4) kemampuan menyajikan dengan menndaftar anggota-anggota himpunan 43\%. (5) kemampuan siswa dalam mengerjakan soal himpunan dengan tipe yang berbeda $40 \%$ mengingat pentingnya materi himpunan agar siswa dapat meningkatkan kemampuan berpikir secara sistematis, menambah kecedasan berpikir, dan mampu melakukan analisis terhadap suatu peristiwa atau kejadian dalam kehidupan sehari-hari.

Berdasarkan hasil observasi yang dilakukan peneliti pada siklus 2 ditemukan data: (1) antusias siswa dalam mengikuti pembelajaran materi himpunan $74 \%$. (2) kemampuan siswa dalam menyajikan himpunan dengan kata-kata 70\%. (3) kemampuan siswa menyajikan notasi pembentukan himpunan $75 \%$. (4) kemampuan menyajikan dengan menndaftar anggota-anggota himpunan 71\%. (5) kemampuan siswa dalam mengerjakan soal himpunan dengan tipe yang berbeda $72 \%$.

Hasil observasi yang dilakukan peneliti pada siklus 2 ditemukan data: (1) antusias siswa dalam mengikuti pembelajaran materi himpunan 96\%. (2) kemampuan siswa dalam menyajikan himpunan dengan kata-kata 93\%. (3) kemampuan berdasarkan siswa menyajikan notasi pembentukan himpunan 97\%. (4) kemampuan menyajikan dengan menndaftar anggota-anggota himpunan 95\%. (5) kemampuan siswa dalam mengerjakan soal himpunan dengan tipe yang berbeda $92 \%$. Terlihat bahwa pendekatan CTL efektif digunakan untuk meningkatkan kemampuan pemahaman siswa pada materi himpunan di kelas VII A SMP Negeri 1 Cisarua.

\section{KESIMPULAN}

Berdasarkan hasil Penelitian Tindakan Kelas (PTK) yang telah dilakukan oleh peneliti, maka diperoleh simpulan berikut: 1) Pemahaman siswa pada materi himpunan di kelas VII A SMP Negeri 1 Cisarua Kabupaten Bandung Barat sebelum menggunakan pendekatan CTL (Contextual Teaching and Learning) kurang nilai rata-rata 58,43 di bawah KKM 70, sementara itu, sesudah menggunakan pendekatan CTL (Contextual Teaching and Learning) pemahaman siswa pada materi himpunan sangat baik nilai rata-rata 94 di atas KKM 70. 2) Pendekatan CTL (Contextual Teaching and Learning) efektif digunakan untuk meningkatkan pemahaman siswa pada materi himpunan di kelas VII A SMP Negeri 1 Cisarua Kabupaten Bandung Barat. Hal ini dapat dilihat dari prosentase kelulusan siklus 1 yaitu 22,85\%, siklus 2 yaitu 71,43\%, dan siklus 3 yaitu 100\%. 3) Ada perbedaan peningkatan hasil pemahaman siswa pada materi himpunan di kelas VII A SMP Negeri 1 Cisarua Kabupaten Bandung Barat sebelum dan sesudah menggunakan pendekatan CTL (Contextual Teaching and Learning). Hal ini dapat dilihat dari hasil nilai rata-rata siklu 1,2, dan 3. Nilai rata-rata siklus 1 yaitu 58,43, siklus 2 yaitu 72,86, dan siklus 3 yaitu 94, ada perbedaan dari siklus 1 ke siklus 2 yaitu 14,43 poin dan dari siklus 2 ke siklus 3 yaitu 21,14 poin. 


\section{DAFTAR PUSTAKA}

Adinawan, M. Cholik \& Sugijono. 2014.Matematika Untuk SMP/MTs Kelas VII Kurikulum 2013, Jakarta: Erlangga.

Afifuddin, Beni Ahmad Saebani. 2012. Metodologi Penelitian Kualitatif. Bandung: Pustaka Setia.

Akbar, P., Hamid, A., Bernard, M., \& Sugandi, A. I. (2018). Analisis kemampuan pemecahan masalah dan disposisi matematik siswa kelas xi sma putra juang dalam materi peluang. Jurnal Cendekia: Jurnal Pendidikan Matematika, 2(1), 144-153.

Anggoro, Toha dkk. 2008. Metode Penelitian. Jakarta: Penerbit Universitas Terbuka.

Ahmadi, Abu dan Supriyono, Widodo. 2004. Psikologi Belajar. Jakarta: PT. Rineka Cipta.

Arikunto, Suharsimi. 2006. Penelitian Tindakan Kelas. Jakarta: Bumi Aksara.

Bernard, M., \& Senjayawati, E. (2019). Developing the Students' Ability in Understanding Mathematics and Self-confidence with VBA for Excel. JRAMathEdu (Journal of Research and Advances in Mathematics Education), 1(1), 45-56.

Bernard, M., Akbar, P., Ansori, A., \& Filiestianto, G. (2019, October). Improve the ability of understanding mathematics and confidence of elementary school students with a contextual approach using VBA learning media for Microsoft Excel. In Journal of Physics: Conference Series (Vol. 1318, No. 1, p. 012035). IOP Publishing.

Bernard, M., \& Senjayawati, E. (2019). Meningkatkan Kemampuan Koneksi Matematik Siswa SMP dengan Menggunakan Pendekatan Metaphorical Thinking Berbantuan Software Geogebra. Jurnal Mercumatika: Jurnal Penelitian Matematika dan Pendidikan Matematika, 3(2), 79-87.

Bernard, M., Sumarna, A., Rolina, R., \& Akbar, P. (2019, October). Development of high school student work sheets using VBA for microsoft word trigonometry materials. In Journal of Physics: Conference Series (Vol. 1315, No. 1, p. 012031). IOP Publishing.

Ditjen PMPTK. 2010. Membimbing Guru Dalam Penelitian Tindakan Kelas Materi Pelatihan Penguatan Pengawas Sekolah. Jakarta: Kemendiknas.

Hamalik, Oemar. 2003. Metode Belajar dan Kesulitan-kesulitan Belajar. Bandung: Remaja Karya. Hidayat, F., Akbar, P., \& Bernard, M. (2019). Analisis Kemampuan Berfikir Kritis Matematik Serta Kemandiriaan Belajar Siswa Smp Terhadap Materi Spldv. Journal on Education, 1(2), 515-523.

IGAK Wardhani, Kuswaya Wihardit. 2008. Penelitian Tindakan Kelas. Jakarta: Pusat Penerbitan Universit.

Insani, S. U., \& Akbar, P. (2019, October). Development of Open-Ended Based Mathematics Problem to Measure High-Level Thinking Ability. In Journal of Physics: Conference Series (Vol. 1315, No. 1, p. 012047). IOP Publishing.

Isnaeni, S., Ansori, A., Akbar, P., \& Bernard, M. (2019). Analisis Kemampuan Koneksi Matematis Siswa Smp Pada Materi Persamaan Dan Pertidaksamaan Linear Satu Variabel. Journal on Education, 1(2), 309-316. 
Mujahid, Imam. 2005. Pembelajaran Berbasis Kontekstual. Jakarta: Bumi Aksar.

Mustaqim \& Wahid. 2010. Psikologi Pendidikan. Jakarta: Rineka Cipta.

Mulyono, Abdurrahman. 2003.Pendidikan Bagi Anak Berkesulitan Belajar.Jakarta: PT Rineka.

Nurhayati, N., \& Bernard, M. (2019). Analisis Kesulitan Siswa Dalam Pemecahan Masalah Matematik Siswa Kelas X SMK Bina Insan Bangsa Pada Materi Persamaan Dan Pertidaksamaan. Journal on Education, 1(2), 497-502.

Purwanto, Muhammad Ngalim. 2006. Prinsip-prinsip dan Teknik Evaluasi Pengajaran. Bandung: Remadja Karya.

Rohaeti, E. E. (2019). Pengembangan Media Visual Basic Application untuk Meningkatkan Kemampuan Penalaran Siswa SMP dengan Pendekatan Open-Ended. SJME (Supremum Journal of Mathematics Education), 3(2), 95-107.

Sudaryono. 2012. Dasar-dasar Evaluasi Pembelajaran. Yogyakarta: Graha Ilmu.

Sudjana, Nana. 2016. Penilaian Hasil Proses Belajar Mengajar. Bandung: Rosdakarya.

Sudiyono, Anas. 2005. Pengantar Evaluasi Pendidikan. Edisi 1, Cetakan ke-5.Jakarta: PT Raja Grafindo Persada.

Sugandi, A. I., \& Akbar, P. (2019). Efektivitas Penerapan Strategi React Terhadap Kemampuan Koneksi Matematis dan Self-Efficacy Siswa SMP. Jurnal Cendekia: Jurnal Pendidikan Matematika, 3(2), 431-436

Tampubolon, Saur. 2014. Penelitian Tindakan Kelas untuk Pengembangan Profesi Pendidik dan Keilmuan. Jakarta: Penerbit Erlangga.

Wiliawanto, W., Bernard, M., Akbar, P., \& Sugandi, A. I. (2019). Penerapan Strategi Pembelajaran Aktif Question Student Have Untuk Meningkatkan Kemampuan Berpikir Kritis Matematik Siswa SMK. Jurnal Cendekia: Jurnal Pendidikan Matematika, 3(1), 139-148 